\title{
Research on Practice Ability Training Mechanism of Young Teacher in Local Colleges
}

\author{
Hongchang Wang \\ Jilin Agricultural University No. 2888, Xincheng Street, Changchun China.
}

Keywords: Young teacher; Evaluation system; Practice ability

\begin{abstract}
Young teachers in colleges are the dominant forces of the teachers in our country, they generally have higher educational background with passion and vitality, are the fresh blood of education industry. The local colleges usually take high-quality practical talents cultivation as the orientation, to require present students to have the innovation spirit and practice ability, which put forward higher demand to college teachers. While most of the young college teachers' teaching experiences and social practice abilities are limited because of short working time, so it is very significant to cultivate the practice ability of these young teachers. This paper focus on the present situation of young college teachers' teaching ability and the cultivation of their practice ability.
\end{abstract}

\section{Introduction}

Teacher is the main part of education career, plays a dominant part in education. Teachers' level and ability will directly affect the whole education quality. As a part of college teacher, the young teachers generally have a higher degree and abundant theoretical knowledges after the professional knowledge training of the undergraduate and postgraduate stage, but the practice ability and management ability in teaching are insufficient, which does not conform to the requirement of local college's education policy in new curriculum reform. At this stage, the local colleges focus on the high quality practical talent training, emphasizes the students' innovation spirit and practice ability. Simple theory infusion is unable to achieve this education goal, therefore, in order to make the students' cultivation meet the social demand for talents and achieve the education goal of local colleges smoothly, the practice ability of teachers should be raised at first, then theory teaching mothed should be changed to practice ability teaching mothed, and finally to complete the smooth transition of double type teaches.

\section{The Present Situation of Young Teachers' Practice Ability in Local College}

\subsection{Young Teachers Generally Lack of Practice Experience}

The young teachers in local college are excellent graduates graduated from university soon, just switch from student status to teacher status. For classroom experience and management experience in the teaching, they haven't contacted both of them in former school life. Single experience makes young teachers feel inadequate inevitably when they contact with the teaching work for the first time, and they have to learn many things from scratch. In the face of some unexpected emergencies, they also lack of corresponding measures to deal with, so they usually at a loss in their internship or practical training period.

\subsection{The Neglect of Local Teaching Environment on Practice Ability}

In the traditional thought of college teaching, the characteristics of emphasize theories and diminish practices has been existed all the time. Many colleges take students' grade and academic achievement as the important standard of teacher assessment. There is no normative and detailed requirement for practical teaching objectives. Which makes the young teachers who are lack of practice ability unaware of their shortcomings even more. The colleges pay no attention to it, and teachers' consciousness also is insufficient, so that many young teachers are wild about dong scientific research and writing disserts. They still focus on theoretical infusion in teaching and ignore the improvement of their own practice ability. 


\subsection{Lack of Practice Ability Training Platform}

The teacher training of many colleges still concentrate in campus, and the training facilities provided to students are limited, so some young teachers could find the platform for practice ability training in daily work. Unsound training mechanism lets the young teachers feel difficult to test the theoretical knowledges they have grasped and translate the teaching theoretical experience into practical teaching experiences rapidly. And even some colleges have established training mechanism, but because of the single training model, still focus on traditional classroom teaching and place emphasis on sharing and communication of practical experiences, it couldn't achieve the effect of young teachers to practice and in depth study.

\subsection{Unreasonable Construction of Evaluation Mechanism}

In the colleges' evaluation mechanism aimed at teachers, the embodiment of the teachers' practice ability in teaching work hasn't been covered by the inspection standards. Because the position is not clear, so college education doesn't have a clear standard for teachers' comprehensive abilities. Teacher evaluation standard is still stay in the traditional development stage, emphasizes academy and despises practice, emphasizes the quantity not quality of a teacher's published papers, emphasizes the academic value of scientific research project but despises the cultivation of practice ability. According to current trends, the young teachers' practice ability raises slowly and cannot get attention and recognition, finally, in order to adapt to school's evaluation standard and survive in this kind of environment, the teachers can only to apply their energy to published papers rather than the study of teaching effect. This is the unreasonable construction of current evaluation mechanism which needs relevant departments to adjust and correct constantly.

\section{The Strategy of Young Teachers in Local College to Improve Practical Teaching Ability}

\subsection{To Strengthen the Concern and Awareness of Young Teachers on Practice Ability}

Along with the development of economy, the society has a bigger requirement for practical talents. With the further social division of labor, people are increasingly aware of the importance of practice ability. It is in this context, colleges have begun to cultivate the practical talents as the guidance, and paid attention to the integration between theoretical knowledge and practice ability. The young teachers want to improve their practical teaching ability, at first, they should transform the traditional thought and realize the importance of practice ability, and to cultivate the practice ability consciously in teaching work according to their own insufficient, update their education concepts in time, and try hard to become the double teacher.

\subsection{To Complete the Training Mechanism for Young Teachers}

The colleges can set up induction training for new teachers, to help new teachers familiar with the work content and establish the direction of teaching. To clear and definite the self-improvement direction of the future according to the education policy of school and the reflection of themselves. The young teachers enter the workplace at the first time, lack of practical experience, just need induction training to help them set up a basic practice teaching concept and let them to improve the practice ability consciously, in order to give full play to in the teaching process, and contribute to the improvement of young teachers' teaching ability. Except induction training, the college can also carry out one help one tutorial system. The so-called tutorial system is to make some veteran senior teachers to help these uninitiated young teachers one-to-one. The young teachers could consult the senior teachers on the questions about teaching experience and class management. This kind of tutorial system could help the new teacher snap into the working environment, and has a promoting references for the practice ability improvement of young teachers.

\subsection{To Strengthen the School-Enterprise Cooperation and Improve the Training Platform}

The most effective method for young teachers in local college to improve their practice ability it to go deep into the social practice, which needs the school to strengthen the cooperation with enterprises, to provide the professional and powerful training platform for young teachers. After all, to accumulate experiences through classroom teaching is not enough. The young teachers also need to go out of school and go deep into the enterprise to understand the mode of its production and management, then combine with their theoretical knowledge to come to the most practical 
professional theory. At the same time, to adjust their teaching direction on the basic of enterprise's requirements for talents' quality and standard understood in practice process, which is important to the improvement of teachers' professional knowledge level and practice ability.

\subsection{To Set up the Reasonable Evaluation System}

For teachers, evaluation system is not only a kind of guide, but also a kind of encourage, scientific and reasonable evaluation system can inspire young teachers' teaching enthusiasm and promote them to study teaching method, update teaching concepts and improve their teaching practice ability constantly. At present, most colleges' teacher evaluation system mainly includes: morality, ability, diligence and achievement, while in the evaluation content of ability, the requirement of practice ability is not standard, doesn't highlight the significance of practice ability in teaching ability, therefore, we should complete the evaluation system for teachers, and put the practical teaching ability into the system linked with performance, salary and professional title appraisal, to encourage young teachers to improve their teaching method and ability in practice.

\section{Conclusion}

At this stage, college education takes the cultivation of practical talents as the main guidance, which requires the college teachers have strong practice ability. Along with the popularization of education and the enrollment expansion of colleges, there are more and more young teachers join the college teacher team. Because the young teachers enter the workplace at the first time, lack of practical experience, so the college should help the young teachers to improve their practice ability by learning and training, and strengthen the emphasis level for practice ability form teaching concept. Establishing perfect teacher evaluation system to help young teachers to realize the improvement and breakthrough of their own ability. Strengthening college teachers' cognitive level of practice ability is a promotion of the whole college education.

\section{Acknowledgments}

This paper is one of the research achievements of Jilin province education scientific planning project.

\section{References}

[1]. Zhang Jin, Zhang Haisheng. Research on the ability training and improvement mechanism of college young teachers [J]. Chuzhou College Journal, 2015 (1): 116-120.

[2]. Zhao Jun, Zhao Shusong. Research on the college young teachers training mechanism based on the ability development law [J]. Science of education, 2016, 32 (2):46-53.

[3]. Ma Yalin. Research on the professional teaching ability and growing incentive mechanism of college young teachers [J]. Heilongjiang Researches on Higher Education, 2016 (2): 112-114. 